$\Gamma=\int Q_{p n}^{4} d t-$ інтегральна функція гідрографа руслової витрати $Q_{P \Gamma}$.

Запропонована методика розрахунку загального розмиву дозволяє оцінити вплив загальних руслових деформацій на стійкість транспортних споруд.

\title{
Література:
}

1. ДБН В.2.3-22:2009 «Мости та труби. Основні вимоги проєктування». Київ, 2009. 367 с.

2. Ткачук С.Г. Прогнозування руслових деформацій на мостових переходах. Частина 3 і 4. Навчальний посібник. К, 2004. 98 с.

3. Ткачук С. Г. Гідравліка. Гідрологія. Гідрометрія: підручник. Київ, 2013. 392 с.

DOI https://doi.org/10.30525/978-9934-588-79-2-2.28

\section{ОСОБЛИВОСТІ ОРГАНІЗАЦІЙНОЇ ТА ФУНКЦІОНАЛЬНОЇ СТРУКТУРИ МОНІТОРИНГУ ДОВКІЛЛЯ ПРИ БУДІВНИЦТВІ ТА РЕКОНСТРУКЦІЇ ОБ'ЄКТІВ ЯДЕРНОЇ ЕНЕРГЕТИКИ}

Осипова А. О.

аспірантка

Київського національного університету будівництва і архітектури

\section{Савенко B. I.}

кандидат технічних наук, доктор технічних наук (РФ), професор

Київського начіонального університету будівниџтва і архітектури

Осипов С. $\mathbf{O}$.

кандидат технічних наук, доцент

Київського наиіонального університету будівнищтва і архітектури м. Київ, Україна

Останнім часом одним із основних напрямків світового технологічного і соціального розвитку є захист біосфери Землі, що обумовлено глибокою екологічною кризою. Для подолання загальносвітової екологічної кризи міжнародним співтовариством у другій половині $\mathrm{XX}$ сторіччя було розпочато поступове впровадження природозахисних заходів і рішень, які з часом набули ознаки системності. Так, від116 
повідно до рішень Програми ООН 3 навколишнього середовища (ЮНЕП) від 1972 [1] та Кіотського протоколу від 1992 років [2],були передбачені та останнім часом здійснюються системні заходи щодо захисту об'єктів природного навколишнього середовища. У 1982 році Генеральною Асамблеєю ООН прийнято Всесвітню хартію природи [3] і Всесвітню стратегію охорони природи,розроблену (1980) [4]. В останні десятиліття XX ст. під егідою $\mathrm{OOH}$ розроблена Концепція сталого розвитку [5], яка передбачає глобальні підходи до охорони навколишнього середовища.

Вирішення проблеми наукового обгрунтування,створення та функціонування екологічного моніторингу процесів будівельного виробництва під час будівництва,реконструкції об'єктів ядерної енергетики дозволяє в режимі реального часу відстежувати контрольовані параметри елементів довкілля, фіксувати моменти перевищення відносно гранично-допустимих рівнів викиду забруднюючих речових та негативних впливів. Основою створення та функціонування екологічного моніторингу є запропоновані моделі його організаційної та функціональної структури. Для забезпечення процесу моніторингу довкілля під час виконання будівельно-монтажних робіт на будівельному майданчику пропонується створення пункту екологічної безпеки,що функціонує на протязі всього терміну будівництва об'єкта. Оперативна локалізація негативного впливу здійснюється шляхом виконання додаткових ревіталізаційних робіт і заходів,у тому числі із застосуванням наявного комплекту інвентаря для негайного та швидкого видалення небезпечних забруднень. Моделі організаційної і функціональної структур включають мету створення та головне призначення (функція) структури, організаційну або функціональну схему, а також елементи матеріально-технічного забезпечення.

В процесі масового будівництва енергетичних споруд відбуваються руйнування природних комплексів навколишнього природного середовища,екосистем,лісів, урочищ та ін., що погіршує екологічний стан та негативно впливає на здоров'я людини $[6,7]$.

В процесі будівництва і реконструкції споруд відбувається викид шкідливих речових багатокомпонентного складу і фізико-хімічного походження - випаровується вода,розчинники, розпиляється у повітрі тонко дисперсні речовини, утворюються дими металів, концентрований пил та аерозолі, генерується шум від працюючих будівельних машин та механізмів, виникають електромагнітні та магнітні випромінювання, змінюються параметри мікроклімату і ін. [8]. 
Енергетичне будівництво посідає вагоме місце серед чинників перетворення і забруднення навколишнього середовища. Існуючі організаційно-технологічні рішення та заходи щодо охорони навколишнього середовища в процесі будівництва промислових, цивільних i, особливо, енергетичних об' єктів недостатньо пророблені та деталізовані,не зведені у впорядковану систему, що суттєво збільшує витрати суб'єктів будівництва на їхнє відновлення. Залишаються відкритим питання оперативного відслідковування стану довкілля під час виконання будівельно-монтажних робіт та оперативного прийняття рішень щодо локалізації виявлених негативних викидів речовин і впливів. Різні аспекти поставленого проблемного питання,стосовно вдосконалення основ природоохоронних заходів в будівництві,у тому числі організації екологічного моніторингу,висвітлені у працях авторів [9-13] та інших працях вчених світового співтовариства [14-23].

В умовах будівництва і реконструкції об'єктів ядерної енергетики питання ревіталізації процесів будівельного виробництва потрібують уточнення. Наукові обгрунтування організаційної та функціональної структури моніторингу довкілля під час будівництва споруд головне питання організації екологічного моніторингу на будівельному майданчику. Мета екологічного моніторингу - оперативне реагування на зміни контрольованих параметрів,що описують поточний стан довкілля де відбувається будівництво. Тому завданням моніторингу є,поперше, своєчасне отримання інформації про стан довкілля, а, подруге, оперативна локалізація негативного впливу на довкілля.

Обгрунтування організаційної та функціональної структури екологічного моніторингу здійснено шляхом експериментального моделювання можливих організаційно-технологічних рішень;при цьому предметом моделювання були:

А. Організаційна структура пункту екологічної безпеки (ПЕБ) з автоматизованою системою екологічного моніторингу (АСЕМ);

В. Функціональна структура екологічного моніторингу.

Моделі організаційної і функціональної структур включають: 1. Мету створення структури; 2. Головне призначення (функція) структури; 3. Організаційна або функціональна схема; 4. Матеріальнотехнічного забезпечення.

А. Організаційна структура пункту екологічної безпеки (ПЕБ) з автоматизованою системою екологічного моніторингу (АСЕМ).

1. Мета створення і функціонування пункту екологічної безпеки захист об'єктів навколишнього середовища від негативного впливу процесів будівельного виробництва. 
Пункт екологічної безпеки створюється на кожному будівельному майданчику та функціонує на протязі всього терміну будівництва об'єкту.

2. головне призначення пункту екологічної безпеки - негайне та швидке видалення з майданчику будівництва небезпечних забруднень та оперативна локалізація негативного впливу,що виявлений засобами екологічного моніторингу.

\section{3. Організаційна схема ПЕБ.}

Персонал пункту екологічної безпеки призначається наказом керівника будівельної організації,персональний склад якого формується в межах існуючого штатного розкладу будівельної організації, при цьому ПЕБ підпорядковано начальнику будівельної організації і безпосередньо начальнику акредитованої будівельної лабораторії.

Функції голови ПЕБ надаються відповідальному інженернотехнічному працівнику 3 відповідною освітою і підготовкою, якій залучається до постійної роботи на будівельному майданчику.

Додаткові ревіталізаційні роботи і заходи виконуються будівельними робітниками,що зайняті на виконанні будівельно-монтажних робіт, та відшкодовуються за рахунок загально будівельних витрат.

4. Матеріально-технічне забезпечення ПЕБ.

Матеріально-технічне забезпечення здійснюється на основі комплектування ПЕБ комплексом спеціально підібраного інвентаря,приладів і обладнання що складається з:

1. Комсплекту інвентарю для негайного та швидкого видалення небезпечних забруднень; контейнери з сорбентами, контейнери для перевезення радіаційних речовин, ємності з піском для зібрання мастила, палива, хімічних добавок;

2. Комплекту приладів і лабораторного обладнання: - газо, пило і шумоаналізатори, вимірювачі електромагнітного випромінювання та радіації, об'єднаних у автоматизовану інформаційну систему збирання та аналізу даних (АСЕМ) для здійснення поточного моніторингу стану елементів довкілля,що руйнуються, - ступеню забруднення атмосферного повітря,вод водойм, грунту і грунтових вод, рівні шумового впливу, електромагнітного та радіаційного випромінювання, характеру та рівнів пошкодження рослинності та фауни.

Структура зазначених комплектів за своїм складом і кількістю залежить від обсягів можливого викиду небезпечних речовин,умов будівництва, характеру розподілу його на технологічні зони та прийнятого складу виконавців - кількості одночасно працюючих ланок робітників. 
В. Функціональна структура екологічного моніторингу регламентує взаємодію інформаційно-керуючої системи з системою датчиків та об'єктом будівництва.

Своєчасне отримання інформації про стан довкілля забезпечується функціонуванням автоматизованої системи екологічного моніторингу (АСЕМ), як інформаційної-керуючої системи у складі апаратнопрограмного комплексу у вигляді комп'ютерної системи потрібної продуктивності та системи під'єднаних датчиків,фіксуючих величини контрольованих параметрів: 1) ступінь забруднення атмосферного повітря (газо-та пилоаналізатори); 2) ступінь забруднення вод водойм, грунту і грунтових вод (аналізатори води, грунту, донних відкладів); 3) рівні шумового впливу (шумоаналізатори); 4) рівні електромагнітного та радіаційного випромінювання (вимірювачі електромагнітного випромінювання та радіації).

Для автоматизації процесів збору поточної інформації та ії статистичної обробки використовується розроблена прикладна підпрограма, реалізована в середовищі MS Excel, PPM Dovkillia Osypova Anastasia.

Ця підпрограма $є$ зовнішньою до інформаційно-керуючої системи та призначена для статистичного аналізу отриманих величин контрольованих параметрів та збереження у базі даних.

За допомогою прикладної підпрограми величини контрольованих параметрів статистично обробляються,звіряються з гранично допустимими рівнями та будуються графіки,що ілюструють динаміку параметру у часі за величиною та наявні моменти і рівень перевищень відносна гранично допустимих рівнів.

Оперативна локалізація негативного впливу здійснюється шляхом виконання додаткових ревіталізаційних робіт і заходів,у тому числі із застосуванням наявного комплекту інвентаря для негайного та швидкого видалення небезпечних забруднень.

\section{Література:}

1. Програма $\mathrm{OOH} 3$ навколишнього середовища (ЮНЕП): https://uk.wikipedia.org/wiki/Програма_OOH_3_навколишнього_середо вища

2. Кіотський протокол: https://uk.wikipedia.org/wiki/Кіотський_ протокол

3. Всесвітня Хартія природи: http://zakon5.rada.gov.ua/laws/show/ 995_453

4. Всесвітня стратегія охорони природи: http://www.cnshb.ru/ akdil/0039/base/RV/003852.shtm 
5. Концепція сталого розвитку: https://uk.wikipedia.org/wiki/ Сталий_розвиток

6. Національний екологічний центр України: http://necu.org.ua/

7. Міжнародний союз охорони природи (International Union for Conservation of Nature): https://uk.wikipedia.org/wiki/Міжнародний союз_охорони_природи

8. Державна служба статистики України: http://www.ukrstat.gov.ua/operativ/oper_new.html

9. Джигирей В. С. Екологія та охорона навколишнього природного середовища: навч. посібник / В. С. Джигирей. - 5-е вид., випр. i доп. - К. : Знання, 2007. $-422 \mathrm{c.}$

10. Стольберг Ф. В. Экология города: Учебник для студ. вузов / Под общ. ред. Ф. В. Стольберга. - К. : Либра, 2000. - 463 с.

11. Сугробов Н. П. Строительная экология: Учеб. Пособие / Н. П. Сугробов. - М. : Академия, 2004. - 413 с.

12. Тетиор А. Н. Архитектурно-строительная экология: Учеб. пособие / А. Н. Тетиор. - М. : Академия, 2008. - 361 с.

13. Теличенко В. И. Эффект экологического резонанса при концентрации строительства (недвижимости) / Теличенко В.И. и др. // Промышленное и гражданское строчтельство. - 2010. - № 6. C. $14-16$.

14. Волошкіна О. С. Питання екологічної безпеки поверхневих водних об'єктів / О. С. Волошкіна, Є. О. Яковлєв; Рада нац. безпеки і оборони України; Iн-т пробл. нач. безпеки. - К., 2007. - 139 с.

15. Вишняков В. Ю. Моделювання техногенно небезпечних ситуацій 3 використанням даних дистанційного зондування Землі / В. Ю. Вишняков, С. О. Сластін. // Екологічна безпека та природокористування: Зб. наук. праць. - 2008. - № 1. - С. 13-22.

16. Екологічна модернізація в системі природно-техногенної та екологічної безпеки / [М. А. Хвесик, А. В. Степаненко, Г. О. Обиход та ін.]; за наук. ред. д.е.н., проф., акад. НААН України М. А. Хвесика. - К.: Державна установа «Інститут економіки природокористування та сталого розвитку Національної академії наук України», 2016. - 455 с.

17. Екологічна та природно-техногенна безпека України: регіональний вимір загроз і ризиків : монографія / С. П. Іванюта, А. Б. Качинський. - К. : НІСД, 2012. - 308 с.

18. Moedinger F. Sustainable clay brick production - a case study [Електронний ресурс] / Fritz Moedinger // SB05 Tokyo: Action for Sustainability - The 2005 World Sustainable Building Conference in Tokyo. - 
2005. - Режим доступу до ресурсу: http://www.irbnet.de/daten/iconda/ CIB4274.pdf.

19. Sonja C. Economic incentives for sustainable construction - the contribution of energy performance-, solar- and photovoltaic contracting / Cypra Sonja. // SB05 Tokyo: Action for Sustainability - The 2005 World Sustainable Building Conference in Tokyo. - 2005. - C. 4101-4108.

20. Gorse Ch. Refurbishment and Upgrading of Buildings / Christopher Gorse, David Highfield/ - 2 edition. New Jork, Spon Press, 2009. - 272 p.

21. Yudelson J. Green Building Trends: Europe / Jerry Yudelson. Island Press, 2009. - $160 \mathrm{p}$.

22. Friedman D. Historical Building Construction: Design, Materials, and Technology (Second Edition) / Donald Friedman. - W. W. Norton \& Company. New Jork - London, 2010. - 320 p.

23. Burton S. Handbook of Sustainable Refurbishment: Housing / Simon Burton. - Routledge, 2011. - 192 p.

DOI https://doi.org/10.30525/978-9934-588-79-2-2.29

\title{
INFLUENCE OF ENVIRONMENTAL ASPECTS OF DESIGN ON THE AESTHETICS OF ARCHITECTURAL SPACE
}

\author{
Pylypchuk O. D. \\ $P h D$,
}

Associate Professor at the Department of Drawing and Painting

Kyiv National University of Construction and Architecture

\section{Krivenko O. V.}

$P h D$,

Associate Professor at the Department of Architectural Constructions

Kyiv National University of Construction and Architecture

\section{Polubok A. P.}

Associate Professor at the Department of Drawing and Painting

Kyiv National University of Construction and Architecture

$$
\text { Kyiv, Ukraine }
$$

Formulation of the problem. Modern construction and urban environment highlight the urgent need for aesthetic perception and the creation of a visual ecology of space (interior and open public space). In such conditions, taking care of the psychological state of people takes a central place 